\section{Features of spatial distribution of benthic infauna in a Mediterranean shallow-water bay}

C. Palacin ${ }^{1}$, D. Martin ${ }^{2}$ and J. M. Gili ${ }^{1}$

1 Instituto de Ciencias del Mar (CSIC), Paseo Nacional s/n, E-08039 Barcelona, Spain 2 Centro de Estudios Avanzados de Blanes (CSIC), Camí de Santa Bàrbara, E-17300 Blanes, Spain

Abstract. The unique hydrography of the Western Mediterranean Sea does not favour the formation of typical estuaries, although it does favour that of other land-sea systems. However, in EIs Alfacs, a shallow-water bay situated in the Ebre Delta (northeast Spain), where there are considerable continental inputs, the distribution pat terns of the macro fauna and the meiofauna reflect a hydrographical regime very similar to that of an estuary. During July 1987, 23 stations were sampled in the Alfacs Bay using plastic cores. The distribution pattern of the meiofauna follows a gradient and presents a less marked zonation than the macrofauna. Nevertheless, in both cases the peak densities of both faunal components are spatially separated from the principal site of freshwater inflow. The average density of the macrofauna (10430 individuals/m2) and the meiofauna (704100 individuals/ m2) occurs in the bay during the period of maximum flow (spring-summer), and as such this bay is one of the most productive areas of the Western Mediterranean.

\section{Introduction}

The dynamic processes of coastal currents and recent changes in sea level have restructured the Mediterranean coast, remobilising sediments and eroding their outline in recent history. Big deltas and coastal lagoons have been formed as a result of these processes. There are few estuarine zones in the Western Mediterranean (Pritchard 1967) because of negligible tidal movements and the large amounts of fluvial deposits, which prevent ingression of marine water.
As recently reported (Morri et al. 1988), there is a certain uniformity detectable in the faunistic composition of various littoral environments that are partially isolated from coastal waters and, in the Mediterranean, have been named "paralic" environments by Guelorget and Perthuisot (1983). Amongst these are coastal lagoons, semi-enclosed bays and small estuaries. Nevertheless, the infaunal structure in each of these communities is different. This is reflected in the faunal distribution patterns, which are sometimes highly characteristic.

Coastal lagoons are one of the most studied systems in the Mediterranean Sea (e.g. Amanieu et al. 1977, Bedulli and Peretti 1979, Guelorget and Michel 1979a, b, Sacchi 1979; Curini-Galleti et al. 1984, Carrada et al. 1987, Gravina et al. 1989). They are characterized by a comparatively small area and exhibit a great variability of physical and chemical parameters. Nevertheless, the uniformity of composition of the species assemblages of these coastal lagoons, along with their long-term stability, are remarkable (Guelorget and Perthuisot 1983, Giangrande et al. 1983-1984). Variations in the population structure of the different lagoons reflect the extent of the inter change between freshwater inputs and the sea (Gravina et al. 1989). In each case where a serial gradation exists, its origin is centred at the interface between marine and freshwater systems (Bacci 1954, Guelorget and Perthuisot 1983).

Coastal zones, such as semi-enclosed bays, that are deeper and more extensive than coastal lagoons, have received little attention in the Mediterranean Sea. Their depth, as well as their sediment structure, seem to be important factors that correlate closely with the species distribution patterns observed. Nevertheless, the relationship between the degree of water-mixing and/or water stratification is probably crucial in determining the abundance of species and individuals (Nicolaidou and Pa padopoulou 1989), and may even result in the total disappearance of a given population (Friglos and Zenetos 1988). The distribution patterns of infaunal species in these environments are largely unexamined. The benthic communities of the smaller Mediterranean estuaries vary both qualitatively and quantitatively, depending on sediment type. A zonation extending from the most inland sites to the adjacent marine habitats was established by Abbate et al. (1988) and Morri et al. (1988).

In this study, the spatial distribution pattern of benthic infauna in a semienclosed coastal bay has been examined in detail. The bay is shallow and, with its extensive surface area, resembles a coastal lagoon. However, it differs from a lagoon in other aspects, namely in its unrestricted communication with the open sea and its 
constant seasonal freshwater input. The latter is similar to that encountered in many estuarine systems. Emphasis has been placed on defining the distribution patterns of macro fauna and meiofauna and their relationship with distribution models defined by the environmental parameters which characterize the area.

\section{Study area}

We conducted our study in the Ebre Delta, on the north east coast of the Iberian Peninsula (Western Mediterranean, $40^{\circ} 33^{\prime}$ to $40^{\circ} 38^{\prime} \mathrm{N} ; 0^{\circ} 32^{\prime}$ to $0^{\circ} 44^{\prime} \mathrm{E}$ ). The Ebre Delta has an extended apron of $350 \mathrm{~km}^{2}$, with two lateral bays. Els Alfacs, the southern bay (Fig. 1), is $50 \mathrm{~km}^{2}$ in area, with a mouth $3 \mathrm{~km}$ in width; the average depth is $4 \mathrm{~m}$ (max. $=6 \mathrm{~m}$ ). The central area is 3 to $6 \mathrm{~m}$ deep and the littoral platform between 0 and $2 \mathrm{~m}$ deep. Both are connected by a narrow slope ( 2 to $3 \mathrm{~m}$ deep). The total water volume of the southern bay is about 200 million $\mathrm{m}^{3}$. Water from the Ebre River reaches the bay through outlet channels across rice fields; 29 to 50 million $\mathrm{m}^{3}$ are transported to the bay from April to October each year ( 7 to $8 \mathrm{mo} / \mathrm{yr}$ ), i.e., a quantity that represents, $<1 \%$ of the total capacity of the bay.

The hydrographical structure of this area is characterized by permanently stratified conditions. However, the hydrography of the region is highly complex and depends on many different factors including seasonal variables (Camp and Delgado 1987). A less-saline upper water layer advances out across the bay towards the sea (Fig. 2A), sliding over a more saline and dense water layer beneath (Fig. 2 B). The water circulation in the bay is regulated by this structure. Because of the shallowness of the margins of the bay and the many days of strong sunshine, evaporation also plays a prominent role in formation of the salinity gradient. As a result of this stratification, the littoral platform of the bay is not affected by the freshwater flow (except in the immediate vicinity of the outlet channels). In the deeper parts of the bay, a much more constant marine-water salinity prevails. The shallow areas are affected by small, sporadic variations in the sea level

Temperature variations parallel those of salinity. Shallow waters exhibit high daily and seasonal variations, while the temperature of the deeper water in the bay is much more stable. Fig. $2 \mathrm{C}$ shows sediment temperatures at the times at which samples were taken. During the day, the sediment temperature is lower in the middle of the bay than at the edge; at night, the opposite situation occurs.

The percentage of silt and clay in sediments is widely accepted as a valid parameter for identifying different sediment types (Fig. 2 D). The distribution pattern recorded for the bay sediments result from its hydrography and bathymetry. Silty sediments are present along the courses of the freshwater outflows, and extend into the bay. The highest percentage of muddy sediments was observed in the middle of the bay (97.96\%). Silty sediments disappeared at the eastern margin of the bay $(0.05 \%)$.

The organic content of the sediment (Fig. 2 E) gradually increased from the northern margin to the centre (7.37\%), and decreased towards the southeastern margin $(0.59 \%)$. Major differences in organic matter content are' revealed by the comparison of surface redox values (Fig. 2F). High redox values were found at the southeastern margin, indicating well-oxygenated sediments. Values declined rapidly towards the source of the fresh-water input, becoming completely reduced at the sediment surface near that outlet channels $(-347.7 \mathrm{mV})$. Inter mediate values were observed in the centre of the bay, but surface anoxia was not recorded.

\section{Materials and methods}

Samples were collected from 23 stations in Els Alfacs Bay during July 1987, using plastic corers. The sampling strategy was designed with reference to the hydrographic conditions of the bay. Sediment samples were taken along two transects; one orientated north to south along the axis of the freshwater input, the other orientated east to west from the open sea and perpendicular to the first transect. Samples were collected only when freshwater input was maximum and all outlet channels were open.

Benthic samples were divided into two faunal fractions, macro fauna and meiofauna. Different corers were used for these: a $200 \mathrm{~cm} 2$ section to a depth of $20 \mathrm{~cm}$ for macrofauna, a $12.5 \mathrm{~cm} 2$ section to a depth of $8 \mathrm{~cm}$ for meiofauna.

Meiofaunal samples were separated in the laboratory using an elutriator (after Boisseau 1957) and collected on a $55 \mu \mathrm{m}$ sieve. Macrofauna were collected on a $500 \mu \mathrm{m}$ sieve. The collected material were preserved in buffered formalin (10\% v:v of a $40 \%$ formaldehyde solution). Characteristic taxonomic groups at each station were defined as those accounting for $>50 \%$ of the taxa present in any given sample. 
Fig. 2 was constructed by interpolation of environmental values between stations and shows general features in the form of contours rather than data points. They were drawn by the Surfer Program. Statistical studies were carried out using the LAWI Program (written by 1. L1 eonart, I.C.M., Barcelona).

\section{Results}

\section{Environmental factors}

Three assemblages: central zone, sandy, and silty (the last comprising two subgroups, S1 and S-2), were revealed by cluster analysis using environmental factors (sediment temperature, $\%$ silt content, $\%$ sediment organic matter and redox potential; Fig. 3). The key environmental features of these assemblages are summarised in Table 1.

\section{Macrofauna}

The mean density of the macrofauna was 10,430 individuals $\mathrm{m}^{2}$ and ranged from 1,850 to 37,150 individuals $/ \mathrm{m}^{2}$. A total of 21 taxonomic groups of macro fauna were identified in the bay, polychaetes, phoronids and amphipods being the most abundant and widespread (Table 2).

The mean densities of the macrofauna were similar in the south of the bay and in the central zone. However, in the northern part of the bay, densities were lower due to the influence of transported sediments and freshwater flow entering the bay through the outlet channels.

The highest macrofaunal densities were observed at sites located on both sides of the outlet channels where these entered the bay. This was predominantly due to polychaete populations. Similar high macrofaunal densities were observed in the samples collected from the slope connecting the central area with the littoral platform, but could not be ascribed to any single macrofaunal group (see Fig. 4A).

Three different assemblages could be recognized as a result of a cluster analysis using macrofaunal data (Fig. 4 B). These corresponded directly to those revealed by the environmental analyses already described, i.e., central zone, sandy area and silty area. Table 3 shows the fauna associated with the different assemblages.

The mean densities of each group of macro fauna in each assemblage are given in Table 2. The central zone was dominated by polychaetes (49.33\%), amphipods $(23.59 \%)$ and bivalves $(16.67 \%)$. In the sandy assemblage, polychaetes, phoronids and amphipods were dominant, accounting for $38.52,35.21$ and $12.66 \%$, respectively. The silty assemblage was dominated by polychaetes $(78.58 \%)$ only.

Although the polychaetes constituted the principal faunal group, the species that characterized each of the three station assemblages were very different. In the central area, Pseudoleiocapitella cf. fauveli Harmelin and Heteromastus filiformis (Claparède) were dominant; in the sandy zone the most abundant species were Paraonis fulgens (Levinsen), Neanthes caudata (Delle Chiaje) and Mediomastus fragilis Rasmunsen; finally, in the silty assemblage, Streblospio shrubsoli (Buchanan) and, to a lesser extent, Capitella capitata (Fabricius) were the key species observed.

As regards the remaining dominant groups, the amphipod species characteristic of the central zone was Pseudoysus kröyeri and the molluscs Abra alba (Wood) and Loripes lacteus (Linne). In the sandy zone, the comparatively high density of the phoronids resulted from the only species of this group that has been found in Els Alfacs, Phoronis psammophila Cori. The amphipod Amphelisca sp. was also an important component of the macrofauna in this latter zone.

\section{Meiofauna}

The mean meiofaunal density was 70.41 individuals $/ \mathrm{cm}^{2}(\max .=162.88 ; \mathrm{min} .=12.96)$. A total of 19 major taxonomic groups were identified: nematodes were the most abundant, followed by polychaetes and harpacticoid copepods at considerably lower densities (Table 4). Meiofaunal densities (Fig. $4 \mathrm{q}$ increased from the silty zone in front of the outlet channels in the northern part of the bay to the sandy zone in the south. Intermediate density values were found in the central zone.

Cluster analysis of the meiofaunal data revealed the same pattern found for macrofaunal data, establishing three different assemblages of sites: central, sandy and silty (Fig. 4 D). Characteristic taxonomic groups are presented in Table 5. 
Differences in meiofaunal distribution were observed in the bay (Table 4): the central zone included nematodes (73.58\%), polychaetes (19.02\%) and amphipods (3.50\%). Amongst the Nematoda, epigrowth-feeders (Type 2A species; Wieser 1954) predominated, but non-selective deposit-feeders (Type 1 B species) were also an important component of the trophic assemblages. In terms of numbers of individuals, Comesomatidae and Xyalidae were the most important families present. The dominant species were the comesomatids Doryiaimopsis mediterranea, Sabatieria praedatrix. The sandy zone included nematodes (87.34\%); polychaetes (5.32\%) and harpacticoids $(14.76 \%)$. Epigrowth-feeding nematodes dominated, and the common families were Desmodoridae, Selachineimitidae and Cyathotaimidae. The most important species were Richtsia vinxae and Paracanthonchus mediterraneus. The silty zone included nematodes $(94.69 \%)$ and oligachaetes $(2.96 \%)$. Epigrowth-feeders, also dominated nematode populations in this area. The most important families numerically were Comesomatidae, Linhomocidae and Xyalidae, and the dominant species were the comesomatids Sabatieriapui puchra and Paracomesoma dubium.

\section{Discussion}

Benthic infauna in the Els Alfacs Bay (northeast Spain) is mainly marine, but its distribution displays spatial variation resulting from environmental factors associated with freshwater inputs. Of these factors, those related to the granulometry of the substrate show the strongest correlation with the distribution pattern of the infauna. This relationship has been mentioned repeatedly (see for example, Nicolaidou and Papadopoulou 1989), but it is of interest to note that this relationship holds true for the fauna in our survey area.

The seasonal freshwater inflow into the bay gives rise to a large amount of terrigenous material. The sedimentation arising from these inputs generates a sediment distribution gradient characterized by a reduction in fine sediment fractions from north to south. Associated with this change in granulometry is a concomitant increase in faunal abundance. This is more clearly evident in the meiofauna than in the macrofauna. Hence, the distribution pattern of the meiofauna provides a better reflection of recent dynamic sedimentary processes (Newell et al. 1990), while the distribution of the macro fauna appears to be related to their preference for more stable habitats.
The organic matter content and the surface redox potential decrease parallel to the decreasing proportions of the finer silt-clay fraction of the sediments. Both factors contribute to the qualitative definition of species assemblages established by other workers (e.g. Armonies and Armonies 1987).

Maximal densities of macro fauna and meiofauna were recorded in the southern part of the bay, where low sedimentation rates were observed. The maximal densities recorded to the east and west of the northern littoral platform are also worthy of note. Here, the faunal peaks may result from the specific conditions caused by their isolation through poor mixing of the water. The bay dynamics favour such highly localized areas, in which the inflow and outflow of water masses is unpredictable and aperiodic. The assemblages of species in these isolated areas were dominated by opportunistic species, and characterized by a great number of individuals representing a few species only.

In the system studied, the biotic and environmental parameters appear to be very closely interrelated; the assemblages defined by environmental factor and those defined by macrofauna and meiofauna correspond exactly. These assemblages are orientated in a north-south direction in the bay. In a typical lagunar system, the predicted direction would be from west (bay mouth) to east, since faunal variability is related to the exchange of water masses, and in bays this results in a gradation of assemblages perpendicular to the point of communication with the sea (Bacci 1954; Guelorget and Perthuisot 1983).

The importance of the influence of continental inputs during a given period of the year is reflected by the sediment zonation. In a similar way to estuaries (Abbate et al 1988, Morri et al. 1988), such zonation in bays is established in relation to the origin of the inputs, and not as a result of the topographic relationship to the sea. Sedimentation patterns are a product of the interaction between marine and fresh waters, combined with the velocity of the carrying waters (Green 1968). Under the unique physical conditions described in the present study, this has established sediment, and therefore faunal distribution patterns in the bay that parallel those found in typical estuaries. Almost all the littoral systems that have been studied in the Mediterranean sea are, to some degree, sheltered and can be described by the term "paralic" areas as conceived by Guelorguet and Perthuisot (1983). Generally, these correspond to coastal lagoons, characterized by sporadic inflows of water of both terrestrial and marine origin. As a result, they display some degree of confinement (Guelorget and Michel 1979 a, b, Sacchi 1979, Guelorget and Perthuisot 1983, Carrada et al. 1987, Gravina et al. 1989). 
In such lagunar systems, the nature of the sediment may be of lesser importance in determining infaunal assemblages, as it is relatively homogeneous. Hydrodynamic factors may well constitute more important regulatory factors (Cognetti 1982), in particular the intensity of the influx and efflux of the sea (Gravina et al. 1989).

In conclusion, we feel that the composition and distribution of the infauna of Es Alfacs bay is intermediary between those of coastal lagoon and estuarine systems. The hydrographical regime is basically marine, but this does not seem to influence sedimentation or sediment distribution. The terrestrial freshwater inputs regulate the distribution of the surface sediment, even though these inputs are not continuous, but restricted to a short period (spring summer) of the year.

Acknowledgements. We wish to thank Dr. M. W. Trett and Dr. R. Sardá for their useful comments and criticism of the manuscript. This work was supported by a CICYT grant, Contract No. AC 16/84.

\section{Literature cited}

Abbate, M., Bianehi, C. N., Damiani, V., Marri, P., Morri, C. (1988). Resultats preliminaires d'un étude hydrobiologique sur l'estuaire du fleuve Magra (Ligurie, Italie). I Hydrographie. Rapp. P.-v. Réun. Commn int. Explor. scient. Mer Méditerr. 31

Amanieu, M., Guelorget, 0., Miehel, P. (1977). Richesse et diversité de la macrofaune benthique d'une lagune méditerranéenne. Vie Milieu 27(1 B): 85-109

Armonies, w., Armonies, M. H. (1987). Synoptic patterns of meiofaunal and macrofaunal abundances and specific composition in littoral sediments. Helgolander wiss. Meeresunters. 41: 83 -11

Bacci; G. (1954). Alguni rilievi sulla fauna di acque salmastre. Pubbl. Staz. zoo I. Napoli 25: 380-396 Bedulli, D., Peretti, E: (1979). Recent development of the macrobenthos in a brackish lagoon of the Po River Delta. Memorie . Soc. Tosc. Sci nat. (Ser. B) 86 (Suppl.): 69-73

Boisseau, 1 P: (1957). Technique pour l'étude quantitative de la faune interstitielle des sables. C. r. Congr. Socs. sav. Paris Sect. Sect. Sci. 1957: 117-119

Camp, I., Delgado, M. (1987). Hidrografía de las bahías del Delta del Ebro. Investigación Pesq. 51: 351 369

Carrada, G. C., Ceccherelli, V. V., Ferrari, L (1987). Les lagunes italiennes. Bull. Ecol. 18: 149-158 Cognetti, G. (1982). Adaptative strategy of brackish-water fauna in pure and polluted waters. Mar. Pollut. Bull. 1:3:247-250
Curini-Galletti, M., Castelli, A., Lardicci, C. (1984). La fauna dei microhabitat salmastri delle isole d'EIba e di Capraia (Taranto, Italy). Oebalia 11 (3 suppl.): 803-865

Friglos, N., Zeneto, A. (1988). Elefsis Bay anoxia: nutrient conditions and benthic community structure. Pubbl. Staz. zool. Napoli (I. Mar. Ecol.) 9: 273-290

Giangrande, A., Gravina, M. F., Gambi, M. C., Fresi, E., Ardizzone, G. D. (1983-1984). Policheti di fondo mobile semichiuse: fattore di selezione in ambiente salmastro. Nova Thalassia 6 (Suppl.): 155163

Gravina, M. R, Ardizzone, G. D., Scaletta, F., Chimenez, C. (1989). Descriptive analysis and classification of benthic communities in some Mediterranean coastal lagoons (Central Italy). Pubbl. Staz. zool. Napoli (I: Mar. Eeol.) 10: 141-166

Green, J. (1968). The biology of estuaries. Sidgwick \& Jackson, London

Greiser, N., Fauvel, A. (1988). Biotic factors. In: Higgings, R. P., Thiel, H. (eds.) Introduction to the study of meiofauna. Smithsonian Institution Press, Washington, D.C., p. 79-114

Guelorget, O., Michel, P. (1979 a). Les peuplements benthiques d'un étang littoral languedocien, l'étang du Prévost (Hérault). Étude quantitative de la macrofaune des vases. Téthys 9: 49-64

Guelorget, O., Michel, P. (1979 b). Les peuplements benthiques d'un étang littoral languedocien, l'étang du Prévost (Hérault). Étude quantitative de la macrofaune des sables. Téthys 9: 65-77

Guelorget, O., Perthuisot, J. P. (1983). Le domaine paralique: expressions géologiques, biologiques et économiques du confinement. Trav. Lab. Geol. Éc. norm. sup., Paris 16: 1-135

Morri, C., Abbate, M., Bianchi, C. N., Damiani, V., Sgorbini, S. (1988). Résultats préliminaires d'un étude hydrologique sur I 'estuaire du fleuve Magra (Ligurie,ltalie). 11. Zonation benthique. Rapp. P.-v. Reun. Commn int. Explor. scient. Mer. Méditerr. 31: p. 65

Newell, R. e., Newell, P. F., Trett, M. W. (1990). Assessment of the impact of liquid wastes on benthic invertebrate assemblages. Sci. total Envir. 97-98: 855-867

Nicolaidou, A., Papadopoulou, N. (1989). Factors affecting the distribution and diversity of polychaetes in Amvrakikos Bay, Greece. Pubbl. Staz. zool. Napoli (I: Mar. Eco1.).10: 193-204

Pritehard, D. W. (1967). What is an estuary? Publs. Am. Ass. Advmt. Sci. 83:3-5

Sacchi, C. F. (1979). The coastal lagoons of Italy. In: R. L. Jefferies and A. J. Davy (eds.) Ecological processes in coastal environments. Blackwell, Oxford, p. 593-601

Wieser, W. (1954). Untersuchungen über die algenbewohnende Mikrofauna mariner Hartböden. III. Zur Systematik der frei lebenden Nematoden des Mittelmeeres. Mit einer ökologischen Untersuchung über die Beziehung zwischen Nematoden-Besied-Lung und Sedimentreichtum des Habitat. Hydrobiologia 6: 144-217 


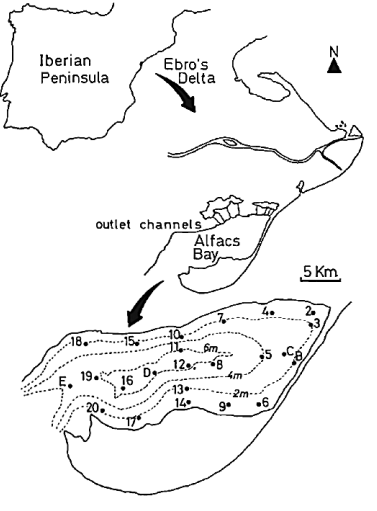

Fig. 1. Study area, showing 23 sampling stations in Alfacs Bay
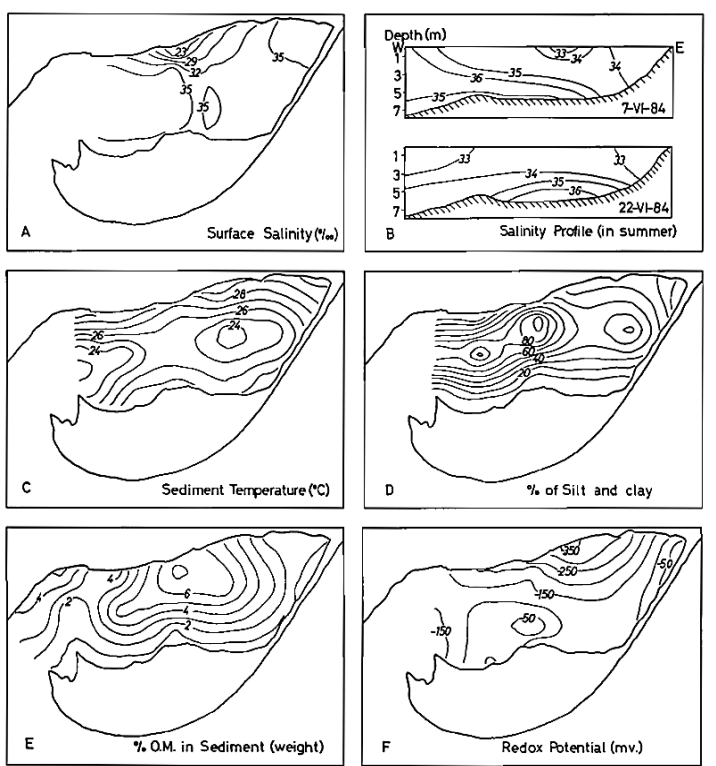

Fig. 2. Spatial distribution of physical factors in Alfacs Bay. All profiles are from east to west (mouth) across bay (from data of Camp and Delgado 1987). Organic matter (O.M.) in sediments was measured by Greiser and Fauvel's (1988) method, the redox potential with a platinum microelectrode.

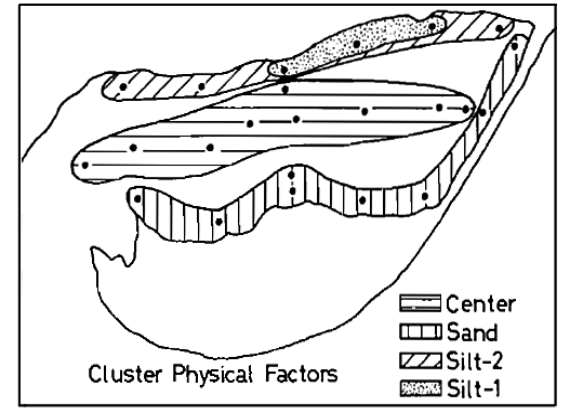

Fig. 3. Spatial plot of groups of four stations obtained by cluster analysis using salinity, temperature, $\%$ silt content, $\%$ organic matter and redox potential of sediment
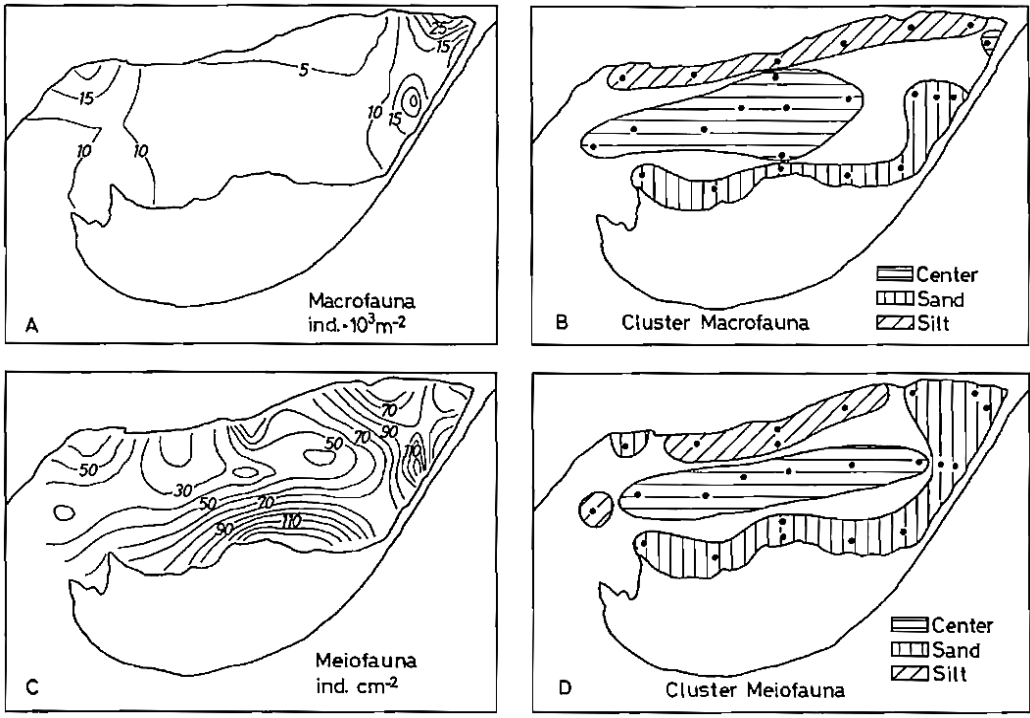

Fig. 4. Spatial distribution of macrofauna and meiofauna in Alfacs Bay (A, C) and of three groups obtained by cluster analysis using macrofaunal and meiofaunal densities 
Table 1. Maximum/minimum values recorded for environmental factors in sediment assemblages revealed by cluster-analysis.

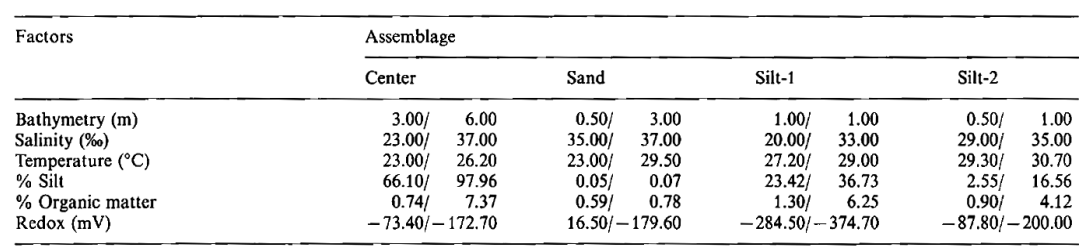

Table 2. Macrofauna. Average density (individuals $/ \mathrm{m}^{2}$ ) in sediment assemblages, presented in order of decreasing abundance.

\begin{tabular}{|c|c|c|c|c|}
\hline \multirow[t]{2}{*}{ Groups } & \multicolumn{3}{|c|}{ Assemblage } & \multirow[t]{2}{*}{ Total } \\
\hline & Center & Sand & Silt & \\
\hline lychaeta & 3683.33 & 4793.75 & 9566.67 & 5604.35 \\
\hline & 127.78 & 4381.25 & & \\
\hline Bivalui & 1761.11 & 1575.00 & 841.67 & 1456.52 \\
\hline $\begin{array}{l}\text { Bivalvia } \\
\text { Tanaidacea }\end{array}$ & $\begin{array}{l}1244.44 \\
3898\end{array}$ & & $\begin{array}{c}625.00 \\
0\end{array}$ & $\begin{array}{l}769.57 \\
263.04\end{array}$ \\
\hline $\begin{array}{l}\text { Tanaidacea } \\
\text { Oligochaeta }\end{array}$ & $\begin{array}{r}38.98 \\
5.56\end{array}$ & $\begin{array}{l}712.50 \\
0\end{array}$ & $\begin{array}{c}0 \\
775.00\end{array}$ & 60.04 \\
\hline & & $\begin{array}{l}0 \\
6.25\end{array}$ & $\begin{array}{l}15.00 \\
0\end{array}$ & $\begin{array}{l}204.35 \\
126.09\end{array}$ \\
\hline & & 156.25 & 191.67 & 117.39 \\
\hline Cuma & & 2.50 & 0 & \\
\hline Anth & 55.56 & & & \\
\hline & 0 & & & 4.78 \\
\hline & 44.44 & 12.50 & 50.00 & 4.78 \\
\hline & $\begin{array}{r}5.56 \\
16.67\end{array}$ & & $\begin{array}{c}25.00 \\
0\end{array}$ & \\
\hline & $\begin{array}{l}16.6 \\
16.6\end{array}$ & & $\begin{array}{l}0 \\
0\end{array}$ & \\
\hline & 5.5 & 25.00 & & 10.87 \\
\hline & 16.67 & 6.25 & & \\
\hline & & 25.00 & 0 & 8.70 \\
\hline & 5.5 & $\begin{array}{l}0 \\
0 \\
0\end{array}$ & ${ }_{556}^{0}$ & $\begin{array}{l}2.17 \\
2.17\end{array}$ \\
\hline $\begin{array}{l}\text { Nematoda } \\
\text { Scaphopoda }\end{array}$ & $\begin{array}{l}0 \\
0\end{array}$ & $\begin{array}{l}0 \\
0\end{array}$ & 8.33 & 2.12 \\
\hline
\end{tabular}

Table 3. Macrofauna. Percentage (\%) of various groups present in each sediment assemblage. - : $<50 \%$.

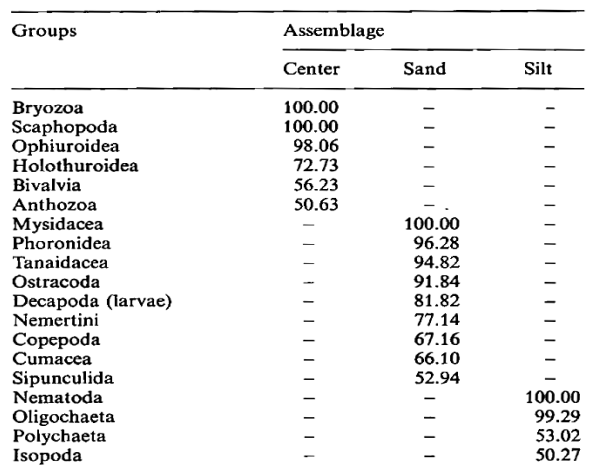

Table 4. Meiofauna. Average density (individuals $/ \mathrm{m}^{2}$ ) in sediment assemblages, presented in order of decreasing abundance.

\begin{tabular}{|c|c|c|c|c|}
\hline \multirow[t]{2}{*}{ Groups } & \multicolumn{3}{|c|}{ Assemblages } & \multirow[t]{2}{*}{ Total } \\
\hline & Center & Sand & Silt & \\
\hline natoda & & 8.23 & 39.90 & 61.00 \\
\hline & 6.24 & & & $\begin{array}{l}4.54 \\
2.57 \\
\end{array}$ \\
\hline $\begin{array}{l}\text { pepoda } \\
\text { istrotricha }\end{array}$ & $\begin{array}{l}0.67 \\
0.11\end{array}$ & $\begin{array}{l}4.81 \\
0.96\end{array}$ & $\begin{array}{l}0.29 \\
0.06\end{array}$ & $\begin{array}{l}2.57 \\
0.54\end{array}$ \\
\hline igochaeta & 0.13 & $\begin{array}{l}0.16 \\
0.16\end{array}$ & $\begin{array}{l}1.25 \\
0\end{array}$ & $\begin{array}{l}0.39 \\
0.38\end{array}$ \\
\hline $\begin{array}{l}\text { Amphipo } \\
\text { Turbellar }\end{array}$ & $\begin{array}{l}1.15 \\
0.05\end{array}$ & $\begin{array}{l}0.16 \\
0.41\end{array}$ & $\begin{array}{l}0 \\
0\end{array}$ & $\begin{array}{l}0.38 \\
0.22\end{array}$ \\
\hline Crustacea (larvae) & 0.03 & $\begin{array}{l}.423 \\
0.23\end{array}$ & 0 & $\begin{array}{l}0.13 \\
0.07\end{array}$ \\
\hline $\begin{array}{l}\text { Bivalvia } \\
\text { Gastropoda }\end{array}$ & $\begin{array}{l}0 \\
0.05\end{array}$ & $\begin{array}{l}0.12 \\
0.09\end{array}$ & $\begin{array}{l}0.03 \\
0.03\end{array}$ & $\begin{array}{l}0.07 \\
0.07\end{array}$ \\
\hline $\begin{array}{l}\text { Gastropodal } \\
\text { Tanaidacea }\end{array}$ & 0.03 & 0.09 & 0.03 & $\begin{array}{l}0.06 \\
0.06\end{array}$ \\
\hline $\begin{array}{l}\text { Ostracodada } \\
\text { Cumacea }\end{array}$ & 0 & $\begin{array}{l}0.12 \\
0.08\end{array}$ & $\begin{array}{l}0 \\
0\end{array}$ & 0.04 \\
\hline $\begin{array}{l}\text { Insectacea (larvae) } \\
\text { Inidaria }\end{array}$ & $\begin{array}{l}0.13 \\
0.03\end{array}$ & $\begin{array}{l}0 \\
0.04\end{array}$ & $\begin{array}{l}0 \\
0\end{array}$ & $\begin{array}{l}0.03 \\
0.03\end{array}$ \\
\hline a armata & 0.03 & & 0 & 0.03 \\
\hline & 0 & 0.0 & 0 & 0.02 \\
\hline $\begin{array}{l}\text { Issopoda } \\
\text { Phoronidea }\end{array}$ & $\begin{array}{l}\mathbf{0} \\
\mathbf{0}\end{array}$ & $\begin{array}{l}0.01 \\
0.01\end{array}$ & $\begin{array}{l}0 \\
0\end{array}$ & $\begin{array}{l}0.01 \\
0.01\end{array}$ \\
\hline
\end{tabular}


Table 5. Meiofauna. Percentage (\%) of various groups present in each sediment assemblage. - : $<50 \%$.

\begin{tabular}{|c|c|c|c|}
\hline \multirow[t]{2}{*}{ Groups } & \multicolumn{3}{|c|}{ Assemblages } \\
\hline & Center & Sand & Silt \\
\hline $\begin{array}{l}\text { Insecta (larvac) } \\
\text { Amphipoda }\end{array}$ & $\begin{array}{r}100.00 \\
87.76\end{array}$ & $=$ & $\overline{-}$ \\
\hline $\begin{array}{l}\text { Polychaetaa } \\
\text { Oryaceda }\end{array}$ & 51.46 & 100 & \\
\hline $\begin{array}{l}\text { Ostracodal } \\
\text { Cumacea. }\end{array}$ & - & $\begin{array}{l}100.00 \\
100.00\end{array}$ & \\
\hline $\begin{array}{l}\text { Nemertini } \\
\text { Isopoda }\end{array}$ & $z$ & $\begin{array}{l}100.00 \\
100.00\end{array}$ & \\
\hline $\begin{array}{l}\text { IIopoda } \\
\text { Phoronidea }\end{array}$ & 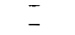 & $\begin{array}{l}\begin{array}{l}100.00 \\
100.00\end{array} \\
\end{array}$ & $\begin{array}{c}- \\
\end{array}$ \\
\hline $\begin{array}{l}\text { Trustacea (larvae) } \\
\text { Turbellaria }\end{array}$ & $=$ & $\begin{array}{l}89.47 \\
88.57\end{array}$ & $\overline{-}$ \\
\hline $\begin{array}{l}\text { Turbellaria } \\
\text { Gastrotricha }\end{array}$ & - & 89.91 & - \\
\hline $\begin{array}{l}\text { Copepoda } \\
\text { Bivalvia }\end{array}$ & $\begin{array}{l}- \\
-\end{array}$ & $\begin{array}{l}89.91 \\
78.95\end{array}$ & \\
\hline Tanaidacea & & 61.40 & \\
\hline $\begin{array}{l}\text { idaria } \\
\text { hinodermata }\end{array}$ & $\begin{array}{c}- \\
-\end{array}$ & $\begin{array}{l}60.00 \\
60.00\end{array}$ & \\
\hline Nematoda & & $\begin{array}{l}57.94 \\
57.94\end{array}$ & - \\
\hline $\begin{array}{l}\text { Gastrtopoda } \\
\text { Oligochaeata }\end{array}$ & - & 50.39 & 80.97 \\
\hline
\end{tabular}

